KINSHIP TIES IN MATTHEW'S MISSIONARY

DISCOURSE:

\title{
A WINDOW ON HOW THE CHRISTIAN FAITH HAS AND WILL ALWAYS AFFECT NATIONAL AND FAMILY TIES
}

TC Rabali

Vaal Triangle Campus: North-West University

\begin{abstract}
Matthew 10 includes sayings in which Jesus is presented as demanding a loyalty that can create enmity among family relations. The statements create a picture of missionaries who are often rejected by their kin while also ministering to people who have been or are being alienated from their relatives. This state of affairs obviously prevailed among Christians of the first century to whom the gospel according to Matthew was addressed. The statements therefore give some insights into Christian family ties and fellowship during the first century. It is the contention of the article that the missionary discourse in Matthew 10 contains useful and still relevant insights about the Christian attitude about family and other kinship ties. It must at least be taken into consideration in attempts to formulate the Bible's teaching about the family and the role of Christians towards their own people and nation.
\end{abstract}

Key Words: Family, Kinship, Matthew 10

\section{Introduction}

Matthew 10 is commonly known as the missionary discourse (Senior, 1977: 101; Barton, 1994: 156). This characterization seeks to capture two matters about the chapter. The first is that the bulk of the chapter is primarily presented by Matthew's gospel as a speech of Jesus. Its form is comparable to that of the other discourses in Matthew, which as Barton (1994: 157) correctly points out are presented by means of a regular pattern of blocks of narrative followed by blocks of discourse in rotating sequence. These other discourses are: The sermon on the mount found in chapters 5 to 7, the kingdom of God parables discourse in chapter 13, the discourse about church related matters of chapter 18, and the eschatological discourses of chapters 23 to 25 (Combrink, 1985: 75,76). The second matter is that the gospel according to Matthew associates the speech with one occasion on which Jesus sent out his twelve disciples to preach the gospel of the kingdom in Galilee (Blomberg, 1992: 165,167). The chapter begins by making clear that the disciples being sent out were also empowered or given the necessary authority to carry out the task for which Jesus was commissioning them (verse 1). It then proceeds by listing the names of the disciples who were sent by Jesus (verses 2-4). The discourse proper begins in verse 5 . 


\section{Some general Remarks About the Content and Context of the Matthew 10 Discourse}

In the discourse Jesus' speech touches on various aspects regarding the mission of the disciples. Some features of the message of the discourse apply only to the specific mission of the twelve with which the discourse is associated; while others, such as their being martyred, obviously would apply to their future mission and that of the church and therefore applies to times and circumstances beyond the historical occasion with which the discourse is associated (Morris, 1986: 140; 1992: 241; Blomberg, 1992: 166). This feature of the discourse makes it a window to both the circumstances during the historical life and ministry of Jesus, including that of His twelve disciples during the pre-crucifixion period, as well as to the conditions regarding the church of the time when the gospel of Matthew was composed. Barton (1994: 161) seems to be drawing attention to this matter when stating: “...Matthew has taken an event in the life of Jesus and the twelve - the sending out on a mission to Israel as part of Jesus' own mission -and made it transparent of the life of the church in his own day." The discourse is part of a gospel that is generally considered by scholars as preserving authentic historical material involved in the ministry of Jesus while at the same time using that same material to also take up issues of concern for the Christian community of the time when it was composed (Senior, 1999: 5). Our approach to this discourse must therefore avoid the methodological mistake of assuming that when a historian wants to communicate a message, he necessarily always has to create the historical data needed (Van Houwelingen, 2003: 186). There are cases when the message can be conveyed by real or genuine historical events. The fact that some aspects of Matthew's missionary discourse apply to the historical circumstances associated with the activities of the disciples prior to the crucifixion of Christ while others clearly only apply to their future work should, accordingly, remind us of this dual nature of the discourse.

Jesus gives the disciples instructions that demarcates their mission field, defines their message and the activities that must accompany it (verses 5-10). He then predicts the responses of those the disciples will minister to (verses 11-20). These predicted responses are in turn used in the speech as the setting for many of the things that he stresses concerning future sufferings and discipleship in general with reference to future circumstances (verses 21-42). The whole discourse therefore is structured in such a way that it moves from the immediate project of the twelve disciples to include more general future events and circumstances (Carson et al, 1992: 63,64). We cannot therefore fully support the suggestion mooted by Sim (1996: 170) that in this discourse "the Matthean Jesus here speaks not to the historical disciples but to the later Matthean community". It is better to view the discourse as both preserving historical statements directed to the historical disciples with whom it is associated as well as also adapting or applying the same statements to the needs and circumstances of those readers being targeted by Matthew.

Christ's three offices of king, priest and prophet are evident in the whole discourse. Commentators have accordingly been quick to point this out (Hendriksen, 1973: 446). It is particularly the prophetic office of Christ that predominates in the whole discourse. The exercise of this prophetic office involves, in the discourse, the elements of predicting the future and revealing things which are hidden to people in general. Much of what Christ reveals in this regard has to do with the responses of the people to the mission of the disciples. He does this in order to teach the disciples the appropriate conduct towards the anticipated reception and rejection that they will experience in the course of their mission. Matthew wrote this discourse as part of his gospel long after the historical events and 
circumstances to which it refers in the life and ministry of Christ. In spite of this, it is best to view the predictions which are presented in the discourse as being founded on actual historical statements which Jesus made, and therefore not as merely and entirely representing after-the-fact reflections or formulations which the Christians made without the necessary historical foundation in the pronouncements and experience of Jesus (Blomberg, 1992: 41,42; Rabali, 1997: 54,55). It is also even possible for the instructions that are preserved by Matthew in this missionary discourse, to have been given repeatedly by Jesus on various occasions (Morris, 1992: 241).

Matthew has placed this missionary discourse between two blocks of narrative material. These narrative sections are respectively Matthew 8-9 and Matthew 11-12. Johnson (1986: 193) has correctly observed that this discourse is therefore placed between the two blocks of narrative material wherein the growing opposition and rejection of Jesus by the leaders of the Jews is being made apparent. Blomberg (1992: 49,165) relates the discourse primarily with the second of these narrative sections and accordingly sees the growing opposition and rejection of Jesus by the Jewish leadership corresponding to that manifested in the discourse as being evident in chapters 11 and 12. It is, however, better to see Matthew 10 as being closely related in this regard to both the narrative material that precedes it as well as that which follows it. In chapters 8-9, this rejection of Jesus by the Jewish leadership reaches a kind of climax in Matthew 9:34 where the Pharisees are reported to have said that Jesus was driving out the evil spirits by the prince of the demons. In the block of narrative material which follows this discourse, namely chapters 11-12, they are reported to have made a similar statement in Matthew 12:24. It is therefore not strange that the whole discourse itself accordingly emphasizes that anyone who does not take his cross and follow Christ is not worthy of being his disciple (verse 38). Harrington (1991: 146) is accordingly correct to remark that the fundamental theological principle underlying the discourse's approach to suffering is "like teacher/master, so disciple/slave. Just as Jesus suffered persecution and division, so the disciple must expect the same".

\section{Israel Needs a Saviour}

Matthew 10 presents the Jews as being in need of a saviour. The narrative sections within which the chapter is placed also makes this very point by drawing the reader's attention to the many people in Israel who had to be relieved of their various needs by Christ, even at odd hours sometimes on Sabbath days (Matthew 8:14-16; 12:9,10). Israel's need for a saviour is also made apparent by the hatred and opposition of the leaders of the Jews to Christ as this enmity identify them as being far from God, even to the extent of being in danger of God's judgment. Scholars such as Carter (2004: 271) have correctly observed that the gospel according to Matthew presents these leaders also as being enemies of God and allies of the devil. In Matthew 12:30-37 Christ accordingly interprets the opposition and curses of this leadership, which they expressed through calling him the prince of the demons, as indicative of their being under God's judgment and displeasure. It is their hatred and opposition to him that makes him compare that wicked generation to a demon possessed person whose condition has become worse in spite of having been freed in the past (Matthew 12:43-45).

The last verses of Matthew 9 which in a way form part of the introduction to the missionary discourse, namely verses $35-38$, also stress the same truth or aspect by noting that Christ saw and pitied the Jewish masses who were flocking to him with their needs. In his great compassion, Christ compared them to sheep without a shepherd. The words 
'sheep without a shepherd' point to people who are in great danger and without the resources to escape from it (Morris, 1992: 239). Carter (2004: 270) correctly draws attention to the fact that the Jewish masses Jesus pitied had leaders who were unfaithful in that they cared for their own interests and who therefore fail, unlike God and Jesus to represent God's just rule. The needs of the masses compelled Jesus to respond in compassion, and the mission of the disciples is therefore presented by Matthew as being an integral part of that response (Senior, 1977:103). In the discourse itself, the depravity and sufferings of the Jews are brought out in various ways. Verse 1 and 8 make clear that the disciples are being sent to a people in great distress, people whose many needs included that of being set free from the power of the evil spirits which the disciples were given the authority to drive out.

It is in accordance with this state of the Jews that Jesus explicitly refers to them as the "lost" sheep of the house of Israel in Matthew 10:6. The "lost" sheep of Israel cannot be taken as a reference to only the outcasts of Israel as Van Aarde (2003: 459) seems to suggest. It should be considered as inclusive of all those among the Jews who were not recognizing Jesus as their Messiah individually and in their relationships. Blomberg (1992: 171) and Morris (1992: 246) correctly therefore make the remark that "lost sheep of Israel" does not refer to a portion of the nation but to all the Jews. It is because of their lost-ness that Jesus instructed his disciples to focus on ministering to the Jews. His focus on the Jews is therefore presented by Matthew in this discourse as being due to the great depravity which he encountered and saw among them. The lost-ness of the non-Jews was obvious but not so apparent to his disciples then was that of the Jews. It does not appear correct to reduce this lost-ness to merely only socio-political conditions of the Jewish masses as people who were politically oppressed by the so-called elites as Carter (2004: 267,268) inclines to.

There is no contradiction between on the one hand, the particular-ism that this focus on the Jews evidences, and on the other hand, the universalism that is also very apparent in Matthew's gospel, as many students of Matthew have observed (Blomberg, 1992:26). The gospel according to Matthew presents Jesus as being interested in both Jews and Gentiles. The particular-ism evident here was demanded by the immediate pressing needs of the Jews and is therefore presented in this discourse as having received a response which highlights the urgency with which Christ approached and sought to deal with those great needs.

The discourse further enhances this matter in its other explicit descriptions of the Jews. For instance, the disciples Christ was sending out were themselves Jews. In spite of this they would have to live and do their work among their "own" people like sheep among wolves (Verse 16). The use of the word "house" in the phrase "house of Israel" in verses 56 reminds one of the truth that all Jews were actually descending from one man, Jacob or Israel, and were accordingly kin. Passages such as Leviticus 19:18 required Israelites to practice deeds of covenant fidelity toward one another, as compatriots and fellow believers (Reid, 2004: 245). The disciples would, however, not everywhere experience the warmth that one would expect in connection with their mission to and movements among their "brothers" and "sisters". On the contrary, Jesus warns them that they must reckon with the reality of the lost-ness of the people among whom they are to minister. This "lost-ness" would manifest itself in hatred and opposition to the message of the kingdom as well as to those who bring that message in God's name. The disciples would accordingly even be handed over to Jewish local councils who after some trials would flog them in their synagogues (verse 17). Their own Jewish people and their own Jewish councils would at 
times even hand them over to Gentile governors and kings (verse 18). This description of the predicted experiences would accordingly mirror that of Jesus in that these were according to Matthew and the other Gospels also basically his experiences.

\section{The Reality of the Cross of Jesus and its Shadow in Matthew 10}

It is too common among New Testament scholars to consider this Matthean way of viewing the Jews as evidence of material in the Gospels which was formed or even created by the early church in accordance with or reflecting the separation of the temple and the church which took place during the post-70 AD period, and therefore as material originating long after the resurrection of Christ. Senior (1977: 11,12) and Van Aarde (2003: 458), for example, view most of the material relating to the Jewish leadership's hatred and rejection of Jesus in Matthew as arising primarily from Matthew's editorial work on Mark and the hypothetical document that is referred to as Q. Luz (2004: 125) even considers, in this regard, Matthew's gospel to be an enlarged "new edition" of the gospel of Mark that resulted in a transformation of the latter. Matthew and the Christian community are supposed to have produced this kind of material for Jewish Christians who were deeply feeling their expulsion from the synagogues after the separation of the synagogue and the church between AD 80 and 90 (Senior, 1977: 11,14). To read this kind of gospel material in this way seems to be the result of divorcing it from the experience of Jesus himself as he moved and ministered among the Jews long before the separation of the temple and the church during the post-70 AD era. His death is the proof that the depravity of the Jews as evidenced in their hatred and rejection of him and of his disciples was a reality even during the pre-resurrection period. It is better to rather operate with the commonly accepted hypothesis that views this kind of gospel material to have been prevalent and in use in the Christian churches of the fifties and forties during the first century long before even the earliest suggested date for the writing of the gospel according to Mark (Smith, 2000: 6). The use of such material among Christians and in first century Christian churches with great significance or relevancy during the pre-70 AD period in the first century may point to the reality of suffering for Christ's disciples even then.

The separation between the synagogue and the Christian church during the post-70 AD period is therefore better viewed as an event that was a further moment or even a climax of a growing hatred dating back to the days of the pre-ascension ministry of Jesus himself. In spite of the fact that Hagner (2003: 197) does not explicitly apply his insight in this regard to the pre-resurrection experiences of the disciples, his position which he terms, gradual transition allows for the approach that we are taking here regarding this matter. He aptly writes: "It seems clear that the operative phrase for this subject must be gradual transition. The parting of the ways between Judaism and Christianity involved a transition that took place gradually and with varying rapidity in different places" (Hagner, 2003: 197). Those who were expressing their solidarity with Jesus by following him during the preresurrection period had therefore, even then, a cross to bear. Jesus was hated and opposed by many of his people's leaders (Van Aarde, 2003: 457,458; Carter, 2004: 271). His crucifixion and resulting death is an event that attests the reality and intensity of that hatred and opposition. Matthew 10 therefore describes the mission of the disciples as well as their predicted sufferings in terms akin to those that the gospel of Matthew uses to describe the mission and sufferings of Jesus (Powell, 1995: 3,4,18,41). It must also accordingly be pointed out that although Matthew 10 speaks about these predicted sufferings in ways which in many respects is similar to those used by many Jewish apocalyptic writings when speaking of the end time sufferings, the reality of Christ's sufferings as attested to by his 
very crucifixion seems to demand that Matthew 10's predictions should not be treated as having simply been due to conformity to the apocalyptic literary convention (Harrington, 1991: 147). An approach that treats the predictions of Matthew 10 as primarily being due to literary convention also seems to tend in the direction of playing down both the historicity of the predictions as well as the reality of the sufferings that many Jewish Christians of the first century experienced in this regard. Long (1994: 50,57) is therefore correct when insisting that when using the approaches associated with genre criticism it is still necessary to acknowledge the pervasive historical impulse that runs throughout Bible sections such as the gospel of Matthew.

In terms of kinship ties, Matthew 10 accordingly can be taken as, among others, conveying the message that this general condition of Israel's depravity serves to highlight the point that the ties that the Jewish leadership and their supporters had with God were no longer close. They were no longer in fellowship with the covenant God who called Israel out of Egypt like a father helping a dear son (Sailhamer, 2001: 89-90; McCartney \& Enns, 2001: 102). Had their relationship to God been a healthy one, they would have been able to recognize and accept Jesus (Matthew 11). Jesus deeply felt their depravity and suffered because of it. Those from among the Jews, his own people who associated themselves with Jesus as his followers, were to have similar experiences and treatments both during the preand post-resurrection periods. Jesus accordingly speaks in the missionary discourse about the violent reactions provoked by the proclamation of the gospel (Reid, 2004: 237,240).

\section{Kinship Terms in Matthew 10}

There is a predominance of kinship terms in the whole discourse. This generous use of kinship terms seems to be in line with what has just been briefly sketched. We shall now try to draw attention to the kinship terms used in the discourse. Louw \& Nida's 1989 useful study of New Testament semantic domains arrange the terms for kinship relations under four subgroups. These are: First, terms referring to groups and members of groups of persons regarded as related by blood but without special reference to successive generations; second, kinship terms involving successive generations; third, kinship terms that refer to relations of the same generations; and fourth, terms having to do with relations based on marriage (Louw \& Nida, 1989: 111-120). It is possible to group the kinship terms in Matthew 10 according to these four categories that are suggested by Louw \& Nida. The present section of this paper will refer to some of the kinship terms in Matthew 10 in the sequence in which they appear in the chapter and will merely identify the appropriate category in terms of the subgroups suggested by Louw \& Nida in some cases merely to show that all the four categories that they identified are represented.

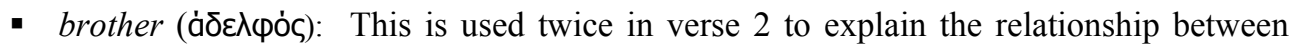
Peter and Andrew as well as that between John and James. The word is employed again in verse 21 when reference is made to a brother who will betray an own brother to death. In terms of the classification in Louw \& Nida, this kinship term designates a relationship that belongs to the third subgroup of kinship relations of the same generation (Louw \& Nida, 1989: 118-119).

- house or family (oiKiac): It is used in its various forms in the discourse. As has already been noted in this paper, the use of "house" in the phrase "house of Israel" in verse 6 refers to the whole nation as one made up of people descending from the same father, namely Jacob whose other name was Israel. One can hardly miss the use of "house" in this sense in this passage as the people are contrasted with the Gentiles and Samaritans. 
Its use in this passage makes even the terms such as "town" or "village" in verses 11 , 14 and 15 acquire kinship significance because it is the villages and towns of the one house of Israel (just as verse 5 speaks of the "towns of the Samaritans" and verse 23 explicitly of the "towns of Israel").

The term for "house" is also used in the sense of home or family (extended family sense) in verses $12,13,14$ and 36 .

It is used with reference to Jesus himself as the head or master of the house who has been abused by being called Beelzebub in verse 25 . This verse makes clear that the members of the "house" over which Jesus is head may be sure of sharing in the humiliation of their master. The discourse accordingly suggests that Jesus is the head or master of a house that could be contrasted with other forms of comparable "houses". This kinship term refers to kinship relations belonging to Louw \& Nida's first subgroup (1989: 113).

- father (патиंр): This term is used in verses 21, 35 and 37. In all these cases it refers to apparently a biological or adoptive human father. In terms of the subgroups of Louw \& Nida, this term and the ones mentioned below under 5.4 and 5.6 through to 5.8 designate kinship relations that belong to their second subgroup of kinship relations involving successive generations (1989: 113-118).

Jesus uses the same term to refer to God as his Father in verses 32 and 33. In verses 20 and 29 he uses it with reference to God as the Father of his disciples. The disciples can count upon the intervening assistance of God their Father through the Spirit when they are under trial. Christ's followers are, accordingly, being encouraged to also depend upon God's care when being betrayed by even their own biological or adoptive human fathers who will be hostile to them for his sake.

- parents (yoveúc): It is used in verse 21 to refer to the relationship of children with their parents. Even parents were going to be rejected by their own children who will even hand them over to death.

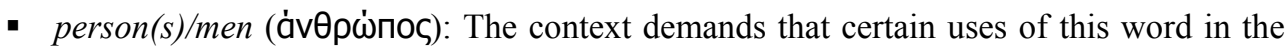
discourse should be taken as having kinship connotations. Louw \& Nida suggest that in contexts where the marital status of the person(s) is being implied, this term can refer to relations belonging to their fourth subgroup of relations based upon marriage (1989: 1190). There can be no doubt that the term is used in such a way in verse 35 where "a man" is set against his father in which case it has to be understood as a grown up married male contrasted with his father. It is even possible that the use of "men" or "persons" in verse 17 also should be understood to be a kinship term for two reasons. First, because the men or persons that are being referred to there were part of the house of Israel. Secondly, because the context goes on to speak of men or persons who are related in verse 21 .

The use of "men" in verses 32 and 33 may also be with kinship connotations in this discourse. The reason for this is not just the fact that the men in view are members of the house of Israel; but primarily because of the parallelism involved. Jesus will acknowledge those who confess him before men who are referred to here before his Father in heaven. The implication of this is that the confession of the disciples is primarily directed to or before all those within their family and ethnic circles including those adult married persons of influence. 
- child(ren) (тغ่Kvov): This is used in verse 21. It refers to biological or adopted children without specifying their gender. This is so because the context associates it with father and parents.

- daughter/son (Өuүáтnр/uiós): These refer to children with their gender being identified. They are used in verses 35 and 37 . The context makes clear that they are employed with kinship connotations.

- mother ( $\mu$ п்тр): This term is used in verse 36. It is where some members who make up a family are being mentioned. The mother is set against her daughter.

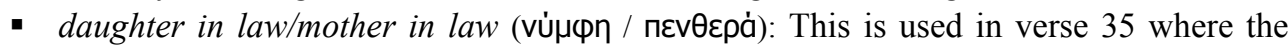
members of a family or household are being mentioned. These terms refer to kinship ties resulting from marriage. It therefore would be an example of a kinship term referring to the fourth Louw \& Nida subgroup of relations based upon marriage (1989: 120). Such kinship ties would also be very important among Jews of the first century because their communities viewed marriage as an essential and cardinal building block of the nation (Lohse, 1980: 85, 149).

The predominance of kinship terms in the discourse implies that many other terms acquire kinship connotations because of their being associated with the kinship terms that are used abundantly in the discourse. It is possible, for instance, that terms like "disciple" and "master" as well as "servant" in verses 24 and 25, have kinship connotations. It is particularly the structural approach to language that compels us to recognize that "linguistic facts are best studied, not as individual entities without relation to other facts, but as parts of a larger system" (Silva, 1990:47). It must accordingly be emphasized that the significance of the individual linguistic words in a chapter such as the missionary discourse of Matthew 10 is better treated when viewed as a function of their opposition or contrast to one another.

\section{Christ Disrupts Kinship Ties}

The discourse makes it clear that kinship ties were going to be adversely affected because of Christ. Christ was himself being rejected by his own people, and those among his people who associated themselves with him were also going to feel the hatred and rejection of their own people. That their sufferings among their people was due to their solidarity with Christ or allegiance to him is clear in the use of the phrase "on my account" in verse 18 (Powell, 1995:18). This is also evident in verse 22.

Part of the rejection by relatives entailed that one could no longer count upon the members of the family to fulfill their roles and obligations as defined by the Jewish law and customs as well as by those of society in general. Hatred and treachery would be visible in relationships which otherwise were expected to be characterized by love and loyalty (Reid, 2004: 241). In a society where the family was the basic socio economic unit, the loss that the early Christians suffered in this regard can never be exaggerated. Their allegiance to Christ brought a wedge in their closest and most intimate relationships, those within their own families (Powell, 1995: 98). Morris (1992:256) rightly observes that the breakdown in the family, the basic unit of society, resulting from one's allegiance to Jesus, cannot be more complete than that which is indicated in verse 21 .

Christ required from his disciples to stand up and be counted particularly with regard to their own people. The responsibility of the disciples included that of calling their own people to repentance with reference to Christ by being faithful in transmitting what he had revealed to them about himself as well as about the depraved state of their own people 
(Powell, 1995: 25). They were to proclaim him and his kingdom publicly and what he had revealed to them in this regard even from the top of the roofs (verse 27). It is clear from the missionary discourse in Matthew 10 therefore that the salvation of fellow Jews involved activities, on the part of both Jesus and his disciples, that often adversely affected family and ethnic ties.

\section{Christ Strengthens Kinship Ties}

It is not all kinship ties that were disrupted, weakened or even torn up by Christ. Some Jewish persons did follow Jesus and formed the core of the early Church. The missionary discourse in Matthew 10 accordingly makes clear that some kinship ties were being and would be enhanced by Christ. Everybody lost some relatives in view of the fact that not all members in the old house of Israel accepted Christ. There were, however, many old kinship ties that were enhanced by Christ. This is apparent from the fact that the early church was initially predominantly or wholly Jewish. The list of the twelve is entirely made up of Jewish persons.

It is within this context that Matthew's list of the twelve may have symbolic significance because that was also the number of the original twelve tribes of Israel (Senior, 1977: 103). Its significance was that a new house of Israel was being built around Christ (Morris, 1992:242). Blomberg (1992:27) therefore aptly notes: "Just as God gave Jacob twelve sons to found the twelve tribes of Israel, Jesus constitutes the new community of God's people with twelve apostles". It was possible within this "new house of Israel", that was being founded in and around Christ, for those who had ties within the old house of Israel to be taken up and therefore for their family and ethnic ties to be enhanced. Indeed, the fact that Matthew 10 speaks about a mission targeting the house of Israel is evidence that Jesus and the disciples made some effort to ensure that many of their kin would also be part of the new house of Israel together with them.

The list of the twelve disciples in Matthew, accordingly seems to be also stressing the fact that there were "brothers" even among the disciples. A comparison with the lists in Mark and Luke brings this out. Matthew lists the pairs of the brothers Peter and Andrew as well as James and John together. The list in Mark 3:16-19, separates Andrew from Peter, and does not explicitly mention the fact that Andrew was Peter's brother. Mark is satisfied to do that with reference to James and John alone, but not so Matthew. The list in Luke 6: 14-16 is closer to that of Matthew in that the first four names are in the order in which Matthew has them. Luke does not, however, mention the fact that James and John were brothers. Matthew mentions this detail with reference to both pairs and even goes further. He lists the names in a way that suggests that the brothers travelled together if Mark's hint that they were sent out two by two is assumed with regard to the discourse in Matthew. Commentators such as Blomberg (1992: 167) and Morris (1992: 243) accordingly draw attention to this pairing although the significance of the kinship relations involved in the pairs is often ignored or treated as though not of great significance. The significance of this matter with respect to the family and other kinship relations is, among others, clearly that these would continue to play an important role within the community that Christ was establishing just as they did in the old covenant.

The discourse also makes clear that some family ties were to be strengthened by Christ through its reference to "peace" in verses 12 and 13. The distinction is made between worthy households and unworthy ones. Christ instructs his disciples in verse 11 to select their hosts carefully on the basis of their faith or attitudes by preferring to be housed in 
homes with "worthy" persons. The disciples offer both the two types of house units, those who deserve and those that do not, peace in the name of Christ. For those who are worthy, that peace becomes a reality. This "peace" apparently included the harmony among family members when whole households aligned themselves with Christ. Powell (1995: 101) has in this context aptly observed that Christ who calls his followers, on the one hand, to renounce relationships that challenge God's reign also calls them, on the other hand, to preserve relationships in deference to that reign. The book of Acts accordingly refers to several such household conversions and corresponding baptisms. The significance of this is, among others, that followers of Christ do also have the responsibility to preserve certain familial, ethnic and national ties by earnestly seeking to win over their kin to the faith that they cherish.

\section{Three Important Kinship Ties that Christ Offers}

What did Christ offer in return for the great loss in terms of kinship ties that his disciples suffered? The discourse stress three matters of great importance. First is the fellowship with Christ and sharing in the rewards that rightly belongs to him (verses 40-42). Concerning the essence of this union with Christ, Gaffin (2003: 177) correctly observes: "There is no partial union with Christ, no sharing in only some of his benefits. If believers do not have the whole Christ, they have no Christ; unless they share in all of his benefits they share in none of them". The disciples therefore had to have some faith in him and his future to can follow him. Christ accordingly taught his disciples through word and deed to rate him and fellowship with him highly. Many of his parables about the kingdom were therefore also meant to clarify the glorious future of his kingdom for them. It would have been difficult, if not impossible, for them to suffer such losses in the area of kinship ties if they did not believe in him in such a way that they rated fellowship with him highly. This faith involved, among others, accepting the central mediating position Jesus assigned himself in the relationship between humanity and God (Hagner, 2003: 2004). Christ accordingly offered them himself and could refer to his disciples as his kin in Matthew 12:46-50. Their future was bound up with his and he accordingly often taught them about his glorious future and that of his kingdom.

Second is the fellowship with the Father that also rightly belongs to Christ. Christ can therefore speak of God as the Father of his disciples in verses 20 and 29. This includes the fellowship with the Spirit. It practically meant, among others, that God would never leave Christ's followers even though their own biological fathers and other such kin could disown them. The discourse accordingly encourages Christ's followers to expect evidences of God's special care for them when they stand trial for Christ's sake (verses 17-20), as well as that God will be able to control all things in such a way that their salvation and his glory will be attained (verses 26-31). In this context, Hendriksen (1973: 473) is justified to observe: "Here God's general providence with respect to all his creatures and his special providence of which all men are the objects make place for that very special watchfulness which he exercises on behalf of those who by virtue not only of creation but also of redemption are his own". The disciples can be certain of this care and salvation in view of the fact that Christ will intercede or own them before his Father in heaven (verses 32-33).

In the third instance, He offers those who belong to him ties with many others who also accept him (verse 42). The missionary discourse anticipates what is later articulated in Matthew's gospel in passages such as Matthew 12: 46-50 and 19: 27-30. Those who belong to Christ are through him also knotted to one another as a family. Christ is after all 
referred to as the master of a "house" in verse 25 and his followers belong to that house together with many others. This should be viewed as part of the foundation for the ability of the Christian faith to transcend ethnic and racial as well as national ties. Van Houwelingen (2003: 187) recognizes this when aptly stating: "The gospel of the Messiah had the power to unite circumcised and uncircumcised, through their common faith." $\mathrm{He}$ accordingly is right to suggest that those Jewish Christians from Jerusalem who sought refuge in Pella, a predominantly Gentile town of the Decapolis region, when the war that resulted in the destruction of Jerusalem's temple around 70AD broke out, could find much assistance from Gentile Christians in that area (Van Houwelingen, 2003: 187).

\section{Some Concluding Remarks}

Christians do not think of Matthew 10 as one of the chair passages to which they should turn in order to learn what the Bible teaches concerning the family, ethnic ties and related matters. It is indeed not such a passage but one that must be seriously taken into consideration in all reflections about the nature of and appropriate attitudes of Christians to their family, ethnic and national ties.

For those contemplating marriage the passage is in line with other Bible passages that warn against expectations of peaceful families when they join themselves with nonChristians in marriage.

This discourse reminds Christians also that the cost of discipleship may at times include the loss of family ties that are dear to them (Senior, 1977: 107). Loyalty to Christ may involve some alienation with respect to various kinship relations such as ethnic and national ties. It therefore reminds Christians that the gospel can sometimes disrupt kinship ties. Christians have at times to be critical to their own people in order to save them.

The discourse also reminds Christians of their special responsibility regarding the duty to spread the gospel among their kin. There are great possibilities for Christians to grow the church by not neglecting their own children, parents, fellow tribespersons, fellow citizens and other kin as well as associated national institutions. The disciples were therefore given the mandate to begin with their own city of Jerusalem in spite of the hatred and opposition they were to face therein. The thrust of the missionary discourse in Matthew 10 is, among others, that Christians have to take the mission to their own nations and kin seriously in spite of the hazards involved.

It is not necessary that the concern to reach own families, and other kin with the gospel should always be viewed as entailing the neglect for those who in kinship terms are aliens. The missionary discourse of Matthew 10 is after all part of a Christian document that powerfully demands that the work of spreading the gospel among the nations be taken seriously. Matthew 10 therefore reminds Christians that healthy "home missions" can exist side by side in one church with "foreign missions".

The missionary discourse in Matthew 10 offers great comfort for those who lost many of their natural kinship ties because of Christ. There are rich rewards. These rewards far outweigh the losses. It is essential to remember these gains when feeling the pain of the losses of the disrupted kinship ties.

Matthew 10 encourages all Christians never to scale down the Gospel when they seek to win members of their tribe, ethnic group or families including their fellow citizens. Blomberg (1992: 181) accordingly correctly points out that although devotion to family is to be viewed as a cardinal Christian duty it must never become absolute to the extent that devotion to God is compromised. Authentic missionary work disrupts certain aspects of 
national and family ties while at the same time being capable of enhancing others. This missionary discourse therefore also reminds African Christians of the truth that the spread of the Gospel in many African communities, as in other communities throughout the world, did and will have similar effects in the future. This is because there are no people who are completely a-religious; and it is therefore only when the Christian faith is superficially accepted that such a state of affairs would not be part of a predictable reality.

\section{BIBLIOGRAPHY}

Barton, SC 1994. Discipleship and family ties in Mark and Matthew. Cambridge: Cambridge University Press.

Blomberg, CL 1992. The new American commentary volume 22, Matthew. Nashville: Broadman Press.

Carter, W 2004. Matthew and the Gentiles: Individual Conversion and/or Systematic Transformation? Journal for the Study of the New Testament, 26: 259-282.

Combrink, HJB 1985. The Gospel according to Matthew: Introduction and Theology. (in Du Toit, AB, editor 1985. Guide to the New Testament volume IV. Pretoria: NG Kerkboekhandel. pp.57-101).

Gaffin, RB 2003. Biblical theology and the Westminster standards. The Westminster Theological Journal, 65: 165-179.

Hagner, DA 2003. Matthew: Apostate, Reformer, Revolutionary? New Testament Studies, 49: 193-209.

Harrington, DJ 1991. The Gospel of Matthew. Collegeville: The Liturgical Press.

Hendriksen, W 1973. New Testament Commentary, The Gospel of Matthew. Edinburgh: Banner of Truth Trust.

Johnson, LT 1986. The Writings of the New Testament. Philadelphia: Fortress Press.

Lohse, E 1980. The New Testament environment. London: SCM press.

Long, VP 1994. The Art of Biblical History. Grand Rapids: Zondervan.

Louw, JP and Nida, EA 1989. Greek-English Lexicon of the New Testament, Volume 1. Cape Town: Bible Society of South Africa.

Luz, U 2004. Intertexts in the Gospel of Matthew. Harvard Theological Review, 97: 119137.

McCartney, D and Enns, P 2001. Matthew and Hosea: A Response to John Sailhamer. The Westminster Theological Journal, 63: 97-105.

Morris, L 1986. New Testament Theology. Grand Rapids: Zondervan Publishing House.

Morris, L 1992. The Gospel according to Matthew. Grand Rapids: Eerdmans Publishing Company.

Powell, MA 1995. God with us, a pastoral theology of Matthew's Gospel. Minneapolis: Fortress Press.

Rabali, TC 1997. Fact and/or fiction in the interpretation of the Gospels. (in Tempelhoff, JWN. Editor. 1997. The exploration of fact and fiction: an interdisciplinary discourse. Vanderbijlpark: PU vir CHE, Vaal Triangle Campus.pp.45-58).

Reid, BE 2004. Violent endings in Matthew's parables and Christian nonviolence. The Catholic Biblical Quarterly, 66: 237-255. 
Sailhamer, JH 2001. Hosea 11:1 and Matthew 2:15. The Westminster Theological Journal, 63: 87-96.

Senior, D 1977. Invitation to Matthew. New York: Image Books.

Senior, D 1999. Between Two worlds: Gentiles and Jewish Christians in Matthew's Gospel. The Catholic Biblical Quarterly, 61: 1-23.

Sim, DC 1996. Apocalyptic eschatology in the Gospel of Matthew. Cambridge: Cambdige University Press.

Silva, M 1990. God, Language and Scripture. Grand Rapids: Zondervan.

Smith, DM 2000. When did the Gospels become Scriptures? Journal of Biblical Literature, 119: 3-20.

Van Aarde, A 2003. Jesus as Joshua, Moses en Dawidiese Messias in Matteus. Scriptura, 84: 453-467.

Van Houwelingen, PHR 2003. Fleeing forward: The departure of Christians from Jerusalem to Pella. The Westminster Theological Journal, 65: 181-200. 